\title{
FORMATION OF THE INNOVATIVE MODEL OF AGRARIAN ENTERPRISES FUNCTIONING BASED ON ECOLOGIZATION AND STEADY DEVELOPMENT
}

\author{
Mariia Bahorka', Iryna Kadyrus²
}

\begin{abstract}
The purpose of the research is to develop an innovative model of developing agrarian enterprises, which will make possible to increase their competitiveness at the expense of implementing modern technologies, types of produce, methods of management, strategy of development. The methodology of forming the innovative model of development at agrarian enterprises considered two types of analyses (internal and external) and included the following stages: analysis of the existing situation; analysis of the external environment; formation and selection of the optimal development strategy; implementation of the selected strategy; monitoring over the process of implementing the strategy. Results were presented in the form of the system for providing ecologically safe agrarian business. Practical results include the formed methods and mechanisms of their implementation towards: provision of the steady development in agribusiness of the region based on the innovative scheme by developing and supporting the organic production; increased employment in rural areas and, as a consequence, partial solution to social problems; provision of population with high-quality local ecologically safe produce. Value/originality. The originality is determined by the implementation of the process of greening the agricultural production in the context of applying alternative management systems, in which agrarian enterprises are considered as the economic ecological system, which is based on rational and ecologically grounded methods of production, by providing the quality of the produce and raw material, production efficiency as well as the minimal impact on the environment and production efficiency.
\end{abstract}

Key words: innovative model, steady development, agrarian enterprises, ecologization of the agrarian production, organic produce, innovative strategy of development.

JEL Classification: M31, O13, Q13

\section{Introduction}

The main trend in modern development of agribusiness is globalization of the economy, which is the multi-faceted and complex process, which is connected with the development of human activity and reveals additional opportunities and economic benefits for all countries in the world. At the same time, this process causes negative consequences, which are manifested mainly in the anthropogenic impact on the environment. There has been a sharp increase in the negative impact of economic activity of a society on the environmental condition during the last few decades. It mainly concerns the area of agrarian production, which is mostly sensitive to any involvement into the development of agrarian ecosystem. Moreover, the actual issue for Ukraine and many other countries in the world is the provision of population with high-quality and safe food products. The main requirements are set not only for the quality of production but also for the environmental conditions.

Modern condition of the market transformation in Ukrainian economy should foresee the transition from the extensive economic development to the intensive but ecologically

\footnotetext{
Corresponding author:

${ }^{1}$ Dnipro State Agrarian and Economic University, Ukraine.

E-mail: bahorka.m.o@dsau.dp.ua

ORCID: https://orcid.org/0000-0002-8500-0362

ResearcherID: G-1646-2019

${ }^{2}$ Dnipro State Agrarian and Economic University, Ukraine.

E-mail: kadyrus.i.h@dsau.dp.ua

ORCID: https://orcid.org/0000-0002-5024-6549

ResearcherID: U-2304-2018
} 
safe, steady economic growth and innovations on the energy and resource-saving base (Vitkov, 2008).

Due to that fact, there has appeared the need for transition of enterprises in agrarian area to new management systems which can provide ecologic and economic balance for the agrarian business. It is worth noting that the transition to the new management system is a complex and timeconsuming process, which could be implemented by developing a new innovative model for developing of agrarian enterprises.

We are certain that the functionality of agrarian enterprises must take place according to the concept of steady development but it requires the creation of completely new conditions for entrepreneurial activity, the base of which is the greening of agricultural enterprise, increase in the efficiency of application of the resource potential of the agro-industrial complex, formation of the ecologically focused management system at the global and regional levels and mainly the provision of population with high-quality food products developed in the agrarian sector with the purpose of rejuvenating the nation. Therefore, we believe it is necessary to develop the qualitatively new innovative model of the managing business activity by agrarian enterprises which will be different from the traditional system of management by conducting ecologically safe agrarian business, its greenings, which is an integral part of the steady development strategy.

\section{Ecologization of production as an innovative component of the model of functioning of an agrarian enterprise}

Functioning of agrarian enterprises according to the concept of steady development requires creation of fundamentally new conditions for entrepreneurial activity, the base of which is ecologization of the agricultural production and increase in efficiency of applying the resource potential of the agro-industrial complex and formation of the ecologically focused system of management.

The ecological component in the agrarian business implies the scientifically grounded complex of mutually connected agro-technical, ameliorative, ground protecting and organizational economic measures at efficient use of the ground, climatic resources, biological potential of plants with the purpose of receiving stable harvest of agricultural crops under the yield increase and keeping to ecological safety of the environment and grown produce (Minkova, 2016). Business entities in the agricultural sector of Ukraine must clearly understand the benefits of organic production (Shkabara, 2014).

I. M. Synyakevych (2005) dealt with greening of the public development as the "concept which implies greening of the economic and social policy and recovery of the spiritual sphere with the help of the system of efficient tools with the purpose of providing steadiness in ecological systems and removal of the global, national and regional ecological threats."

Scientific publications state that the humanity starts to deeper comprehend the threats from negative trends in dynamics of condition indicators in social and ecological components of public development therefore insists on transition toward ecologically clean production (Shubravska, 2007).

The concepts of developing the objects of management took place simultaneously with the changes in attitude to the economic development and formation of the ideology of steady development (Vichevych, 2002).

The ecologically-focused production is understood "as such which takes place on the base of the rational implementation of agricultural grounds with the application of adaptive landscape system of husbandry in combination with their biologization and moderate chemical changes of technological processes" (Nikitina, 2005).

Ecologization is the main direction in the activity of agrarian enterprises and it is based on mastering ecological and economic methods of business activity with the aim of providing the extended recovery of the natural resources at the expense of forming steady ecological and economic systems, increase in the amounts of production of competitive ecologically safe production, creation of agricultural systems using ecological methods of management.

Ecologization of the business activity of agrarian enterprises implies the system of aimtargeted transformations in the productive forces and production relations, which decrease the negative impact on the environment and provide efficient use of resources in the process of production, storing, transportation and distribution of produce. Ecologization is based on principles of ecological safety priority, ecological responsibility, environmental 
protection, restoration and saving of the natural resources, preservation of the landscape integrity and biological biodiversity.

The modern economic direction in the business activity of agrarian enterprises in our opinion can be determined through the combination of economic and social problems of the rational use, recovery and protection of natural resources of agri-sphere and on the innovative base. We consider that greening of the production at agrarian enterprises is tightly connected with the innovative activity and should be considered as an integral part of its development with the creation at the government level of the system of ecological and economic management. Therefore, the organization of the production relations in agriculture should take place based, on the one hand, on the rational application of the natural resources, and on the other hand, on the formation of the system of managing them. To achieve this it is necessary to apply innovative technologies - economic models which based on the usage of biological husbandry elements and optimization of the production processes will make possible to achieve a high level of management, predictability and efficiency. Unlike traditional technologies they are based on the use of energy- and resource-preserving systems of husbandry (Syrtseva, 2008).

The result of application of innovative technologies in agrarian production is the creation of the innovative production.

Ecologization is the direction of the innovative development of agrarian enterprises which are based on mastering ecological methods of management. It provides a wide recovery of natural and anthropogenic resources at the expense of forming steady ecological and economic systems directed at the increase in the amounts of production of the competitive produce, with the application of ecological methods of management based on the implementation of adaptive landscape systems of husbandry, rational involvement in the economic turnover and increase in the efficiency of applying natural material and work resources in the rural area.

\section{Basic components for the innovative model of the functional agrarian production}

The prospect for development of small, middle and large commodity enterprises directly depends on the correctly chosen aim and strategy of development.

The main strategic directions in the innovative model of agricultural producers can be formed due to the following criteria:

- ecological - be useful for the environment, lead to health improvement of people, grounds and eco-systems, maintenance of the ecologic balance in the biosphere;

- economic - provide implementation of the strategy of development by organic manufacturers in the direction toward increase in profits, decrease in costs, increased efficiency of management;

- market - widening of the part of organic manufacturers at the market of production, lead to their concentration and differentiated scientificcommercial activity;

- publicity - encourage the increase in the professional activity among agrarian producers, creation of new jobs and improvement in the working conditions and quality of life in rural areas.

The base of building the innovative model of functioning of agrarian enterprises is their corresponding actions in the process of transformation to the ecologically focused development. For the correct stimulation of those actions it is necessary to have the motivational mechanism, with the basic components - instruments of motivating the innovative development of agrarian enterprises and instruments of greening agrarian production. The base of the motivational mechanisms in our opinion is the awareness of motivating the ecologically focused behavior of customers and motivation for greening the production. Consumers' motivation and motivation of the ecologically focused production are the basics of this mechanism.

Key directions of transiting agrarian enterprises to the model of the innovative development based on greening and steady development are represented in Figure 1.

To implement those directions it is necessary to undergo a whole set of qualitative transformations which concern the transition to the innovative market, renovation of the production system, overcoming the significant differentiation of approaches, that is the global modernization of the national economy is needed.

We outlined main components of the innovative model in functioning of agrarian enterprises based on principles of greening and steady development (Figure 2). 


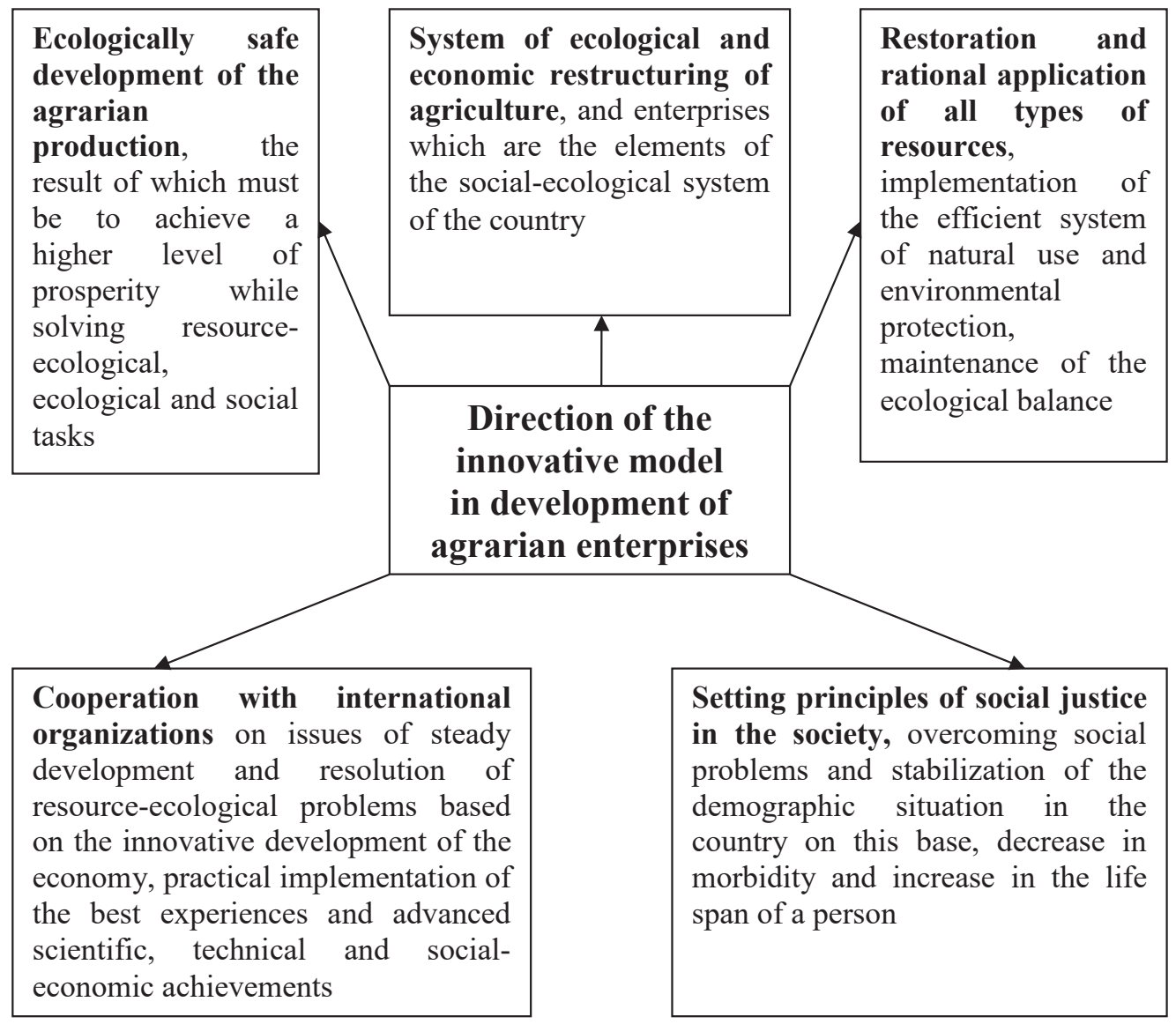

Figure 1. Main strategic directions in the innovative model of developing agrarian enterprises

Source: generalized by the authors

A large-scale implementation of the greening production at the agrarian enterprises is impossible without ecological social awareness. At the country level the greening of the ecological development does matter, which is considered in the context of the economic, social and spiritual spheres as the process, which provides the movement of the earth's population toward steady ecologically balanced development (Haidutskyi, Hodakivska, 2012). Ecologically aware activity and competitiveness of the agrarian business is achieved by convincing the customers of the highest consumption value of ecologically clean produce and support of the image of enterprises on its development. The ecological component must be considered while making any business solutions.

The material base of the motivation of work is stimulation, which is based on the process of external influence on the interests of the business entities with the help of a certain set of actions (moral, material, social), which could encourage the positive development of social relations between business entities and formation of the new type of a personality. We can state that stimulation of the ecologically safe development of the agrarian production must have, on the one hand, the material ground for agrarian producers, and on the other hand, not material loading which will make possible to obtain a certain status in the society. The base of the economic regulation of the ecological activity of agrarian enterprises is the opportunity to regulate the economic activity of enterprises by the government based on economic methods, which are formed based on the redistribution of funds from the producers of non-ecological goods to the producers of ecological goods.

In our opinion the key moments to solving the issue of ecological provision of enterprises, which will make possible to create a fully functioning sector of producers of ecologically clean produce, should be the material stimulation and changes in the internal philosophy of conducting agrarian business. 


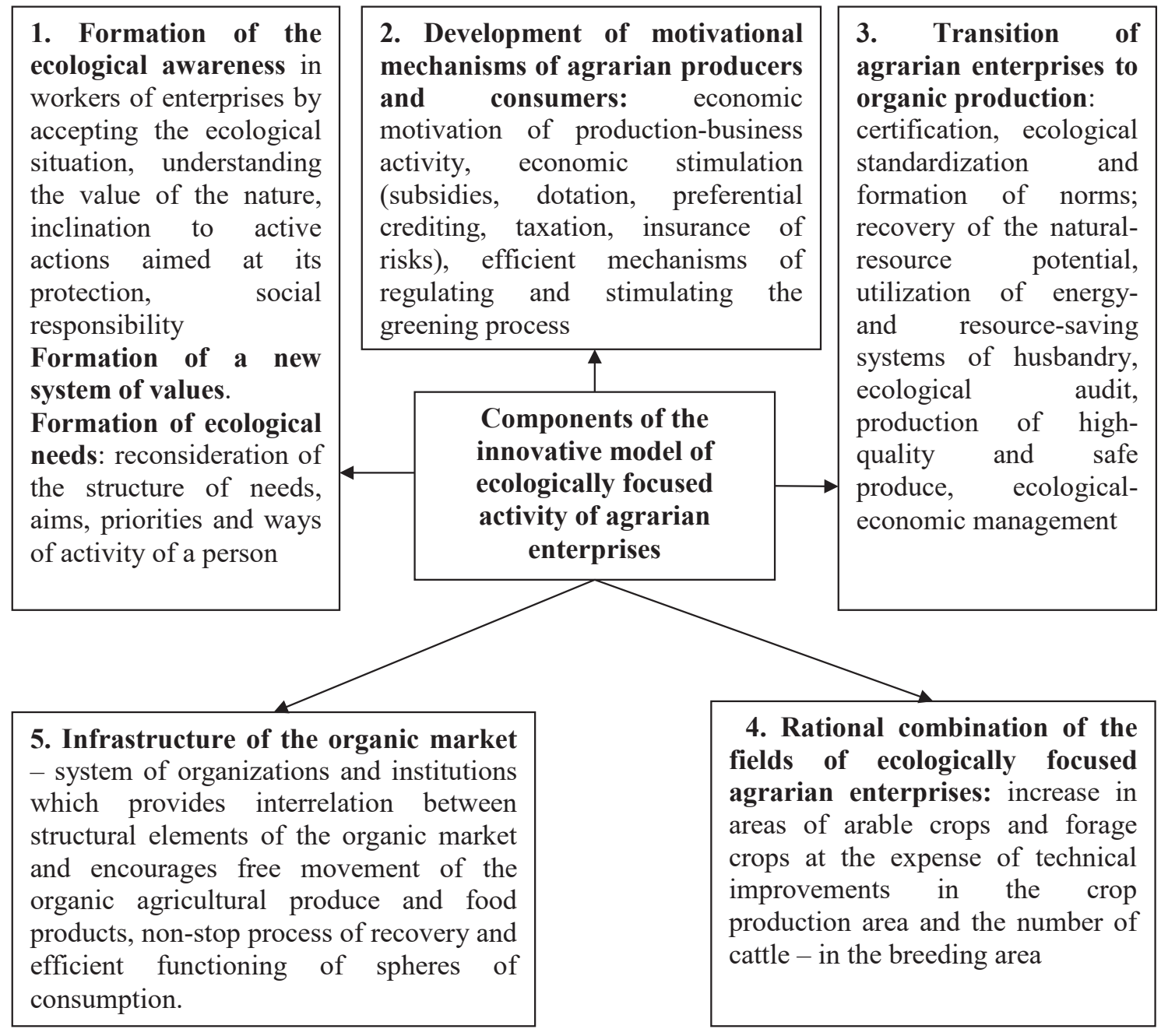

Figure 2. Model of ecologically focused mechanism of management in the agrarian production

Source: developed by the authors

Ecological advantages make possible to solve the issue of providing people with high-quality products without breaking the ecological balance and not harming the environment. Therefore, organic production is spread in different countries of the world, and modern trends of developing the market of organic produce are under the influence of general and global trends.

The radical way of solving the issue of the ecological safety of technologies for growing agricultural crops and ecologically clean produce should be the transition to the organic production as an alternative model of business activity, but at the same time we understand that, currently there are no considerable alternatives to intensive technologies in the global scale since the main problem of many agrarian producers is the maintenance of the yield. The transition period from traditional (intensive) technologies to organic technologies is a rather long-term process. Depending on the situation, it can last from 2 to 5 years and it can be accompanied by certain risks.

Ecologically focused transformation of the production activity of agrarian enterprises includes the following:

- rational use of land which is accompanied by maintaining and increase in soil fertility;

- provision of the optimal level for ploughing arable grounds which prevents water and air erosion of soil;

- keeping to standards for the limited norms of pollutants in the production, provision of green production;

- compliance with the set rules toward transportation and application of mineral fertilizers, means of protecting plants and animals;

- prevention of the chemical contamination of the environment and food products; 
- keeping to ecological requirements while designing, building, reconstructing and use of new buildings and constructions, ameliorative systems and so on.

An essential condition for functioning of the innovative model is the efficient combination of areas of the organic enterprises in compliance with the natural-ecological standards. Such a combination should provide the optimal economic efficacy of land usage; relatively balanced use of machinery and workforce during the year (in the area of husbandry and breeding) to reduce the seasonal effect of the agricultural work; rational and maximal possible application of the produce of one field by the other field; more efficient and fast money turnover; bigger produce output, achievement of the maximal level of work productivity and the figures of the profit. The main task of specialization and concentration is the significant increase in the amount of production and distribution of the agricultural produce, their quality, increase in productivity, and decrease in costs.

At the expense of the constant optimal planning and predicting the rational combination of the areas, it is possible to find the transition from the traditional business activity to the organic one with the least losses and risks as well as to achieve the economic effect (increase in profitability, gross produce or decrease in costs caused by production), social (employment of people in rural areas, increase in the level of workers' life), agro-ecological (improvement in the structure of soils, their physical and phytosanitary conditions, air and water modes, positive balance of humus, development of biogenic elements, ecological characteristics of the created products).

Accordingly, the improvement in the field structure of organic enterprises by the criterion of implementing the strategy of greening the production implies the increase in the arable areas of grain crops and forage crops at the expense of the technical processes - in the husbandry area and increase in the cattle - in the area of breeding.

One of the leading positions in the innovative model of development is taken by the infrastructure of the organic market as a system of organizations and institutions, which provide interconnection between structural elements of the organic market and leads to free movement of the agricultural organic produce and food products, non-stop process of creation and efficient functioning in the sphere of the end-user. The creation of conditions and acting mechanisms for developing and efficient functioning at the infrastructure of the market of the organic agricultural production is the main task of the country. It is essential that formation of the infrastructure at the market of agricultural produce should take place under the conditions of cooperation among all their structural elements and development of them as the integral system: organizational, creditcalculating, logistics, informational, human resources. The infrastructure should serve the process of the market exchange of goods in the organic sector, provide the reliability, transparency and stability of the sector.

To carry out the process of transition from the traditional to the organic business activity it is necessary to mobilize own funds and possibilities of agrarian enterprises in Ukraine. It can be recommended to borrow the experience from the developed countries in the world; in those countries, the government plays the main role during this transition, and it is the government who is interested in positive ecological changes; therefore, it creates the efficient mechanism of environmental regulation and determines strategic priorities in the sphere of transition to the production of the organic agricultural production.

\section{Conclusions}

The innovative model of developing the agrarian production should be based on the overall consideration of ecological factors, requirements to the ecological safety of any production process, rational use and preservation of natural resources. Owing to those factors, the society will be able to overcome the ecological crisis and create such conditions under which the agrarian production will develop intensively, competitively and at the same time ecologically safe.

As a result, the production activity of agrarian enterprises may be transferred to the fundamentally new economical-technological base, structural transformation of production must be made considering ecological factors, laws, requirements and standards, which is an obligate condition for overcoming the ecological crisis in the country. While implementing the main tasks of greening it is possible to significantly decrease the manmade pressure on the environment, improve its conditions which will help Ukraine perform the obliged duties on environmental protection and 
gradual achievement of the European regulations and standards on the boundary levels of harmful influence on the environment.

Essential ecological preconditions for development of ecologically focused innovations are resource and energy conservation. Those criteria are especially important under conditions of limited and exhausted natural resource potential of Ukraine.

The structure of the agrarian production should provide the minimal anthropogenic influence on the environment. At that, it is necessary to carry out the estimation of social-ecological status of the territories and estimation of the ecological condition of carrying out the business activity. That estimation should be made in accordance with the world trends on development and international standards.

The main directions determined in the development of the organic agrarian enterprises include the following measures: organization of the informational campaign on increasing the level of public awareness of advantages in the organic agricultural production and organic products; promotion of the steady agrarian cooperation and establishing the joint distribution of the organic produce, supply of the biological measures for protecting plants and animals; formation of the national system of certification and control over the quality of the agrarian produce; organization of special places in agricultural markets and the chain of distributing the organic produce by creating special retailing establishments for sales and distribution; organization of special fairs, exhibitions and other promoting events; activation of commodity exchange and formation of transparent market conditions for price-making and distribution of significant amounts of the organic produce at the regional, national and international markets; setting up win-win partner relations between producers of the organic produce and other operators of the agricultural market.

The main indicators of the efficiency of the innovative model for development of the agrarian enterprises is quality (economic, ecological, socialinstitutional and stages of harmonization) and life safety of the population.

\section{References:}

Vitkov, M. S. (2008). Intensification of the agricultural production on the innovative base: Monograph. Kyiv: NNC IAE, 220 p.

Minkova, O. H. (2016). Methods and ways of transiting from the traditional agrarian production to the organic one. Bulletin of Uman National University of Horticulture, vol. 1, pp. 3-10.

Shkabara, T. L., \& Ostapenko, A. Y. (2014). Ecological potential of domestic agricultural management in today's processes of European integration. Scientific Bulletin of KSU, vol. 7, pp. 131-135.

Synyakevych, I. M. (2005). Ecologization of the development: essence, objective need, principles, instruments and prospects for Ukraine. Scientific Digest of UNFU, vol. 15.6, pp. 98-102.

Shubravska, O. V. (2007). Risks of steady development of AIC in Ukraine under conditions of globalization. Economy of Ukraine, vol. 2, pp. 62-68.

Vichevych, A. M., Vaidanych, T. V., \& Didovych, I. I. (2002). Ecological Marketing: textbook. Lviv: UkrDLTU, 248 p.

Nykytyna, Z. V. (2005). Ecologization of industrial agricultural enterprises. Agrarian Science, vol. 6, pp. 14-15.

Syrtseva, S. V. (2008). Innovative potential as a component of the economic potential of an agricultural enterprise. Digest of the Agrarian Science of Prychornomoria, vol. 4(47), pp. 115-121.

Haidutskyi, P. I., \& Hodakivska, O. V. (2012). Ecologization of the social consciousness and development of the agrarian sphere. Economy of the AIC, vol. 11, pp. 15-21.

Bagorka, M. (2017). Methodological instruments for forming the marketing strategy of agricultural production ecologization. Baltic Journal of Economic Studies, vol. 3, no. 4, pp. 7-11. doi: 10.30525/ 2256-0742/2017-3-4-7-11 